\title{
The Role of Conformity Towards the Self-Control on Adolescence Cyberbullying
}

\author{
Michelle Velensia ${ }^{1}$ Naomi Soetikno ${ }^{1 *}$ Jessica Chandhika $^{1}$ \\ ${ }^{1}$ Faculty of Psychology, Universitas Tarumanagara, Jakarta 11440, Indonesia \\ "Corresponding author. Email: naomis@fpsi.untar.ac.id
}

\begin{abstract}
Cyberbullying is a form of bullying that occurs through the use of electronic communication technology or other digital media and is rife, especially among teenagers on the social networking site Instagram. Peer relationships influence adolescents to conform to peer groups and can lead to the involvement of teens in deviant behavior, such as cyberbullying. The existence of self-control is associated with the ability of adolescents to avoid demands for conformity from their peer groups. The aim of this study was to examine the role of Conformity toward the Self Control in cyberbullying perpetration among adolescents on the social networking site Instagram. This study involved 176 respondents, and aged 12 to 21 years. This study used quantitative nonexperimental approach with regression analysis technique. Researchers use three measuring instruments, including Conformity Scale, Self-control Scale, and Cyberbullying Offending Scale for screening. The results of data analysis show $\mathrm{t}=-4.695, \mathrm{p}=0.000, \mathrm{R}$ square $=0.112$, these means that conformity has a significant role to adolescence cyberbullying perpetrator self-control.
\end{abstract}

\section{Keywords: Conformity, self-control, cyberbullying, adolescents}

\section{INTRODUCTION}

The advancement of communication technology which is growing rapidly every year has helped increase the use and popularity of social media [31]. Based on a survey conducted in 2020, there were 3.8 billion people worldwide who are active users of social media, and this number of users is expected to continue to increase to reach 4.41 billion in 2025 [5]. Meanwhile, in Indonesia, 160 million people are registered as active users of social media (Kemp, 2020). Instagram is one of the photo-based social networking sites that is currently experiencing increasing popularity and growing rapidly since it was developed in October 2010 [4] [10] with a number of users worldwide reaching more than 1 billion users [5]. Based on a survey conducted in 2020, it was recorded that as many as 63 million people in Indonesia are users of the social networking site Instagram, and are dominated by users from young people and teenagers [11].

The popularity of the use of social media and social networks such as Instagram has not only had a positive impact on its users, but has also allowed negative impacts to emerge for users. One of the negative impacts that coincide with the increasing duration of use of social media and social networks is cyberbullying [12] [16]. Cyberbullying is a form of bullying that involves the use of electronic communication technology or other digital media [12] [28].

Based on a survey conducted by the British Anti-Bullying Organization Ditch the Labels in 2017 involving adolescents aged 12 to 20 years, it is known that as many as
$69 \%$ of adolescents stated that they had done something rude and abused others online, with Instagram being a networking site social media is the most widely used for cyberbullying, and involves many users from adolescents, where as many as $42 \%$ of adolescent social media users are known to have experienced cyberbullying on Instagram [6]. Bohang [3] reveals that cyberbullying that occurs on Instagram includes giving negative comments on certain uploads from other users, unfriendly personal messages, and spreading other users' posts or profiles with ridicule and swearing.

Several previous studies have stated that the relationship between adolescents and their peer groups has played an important role in adolescent behaviour to engage in cyberbullying [22] [27]. One of the things that underlies this tendency is the reality that adolescents have a strong desire to be accepted and liked by their peers [23]. This can be a pressure on adolescents and influence them to conform to get recognition from their peer groups [26]. However, adolescents who are in the scope of negative or deviant friendships also have a greater chance of engaging in deviant behaviour as is done by peer groups [8], one of which is cyberbullying. Several previous studies have found a significant positive relationship between conformity to peer groups and cyberbullying behaviour [15] [18].

Related to the demands for conformity from peer groups, adolescents who can refrain from conforming to cyberbullying activities carried out by peer groups can be said to be adolescents who have self-control abilities. The existence of self-control can help adolescents to assess group activities that are positive or negative or deviant for 
themselves as a consideration in making decisions to conform or avoid demands for conformity from peer groups [7]. Myers and Twenge [21] also revealed that adolescents with high self-control had a lower likelihood of conforming to their peer groups.

However, individuals with low self-control have a stronger tendency to engage in deviant behaviour, criminal behavior, drug use, and aggression towards others, including bullying. Several previous researchers have also consistently found a relationship between self-control and cyberbullying [14] [17], in which low self-control is a significant predictor of cyberbullying behaviour, while high self-control can reduce youth involvement in cyberbullying. Therefore, in this study researchers are interested in knowing the role of conformity toward to the self-control of adolescence cyberbullying perpetrators who use Instagram.

\subsection{Conformity}

According to Taylor et al. [33] conformity is defined as a person's tendency to change their beliefs and behavior to suit the behavior of others. Myers [20] also argues that conformity is a person's tendency to change their behavior or beliefs due to pressure from the group, where the tendency to adjust or equate behavior with a group is carried out in order to avoid criticism and isolation from the group. Brown and Theobald [25] added that a group will influence its group members through various rules and pressures, as well as negative consequences given to members who do not comply with these rules and pressures.

\subsubsection{The Aspects of Conformity}

Myers [20] states that conformity is formed based on two main aspects, namely normative influence and informational influence. Normative influence is an aspect of conformity which refers to social influence based on the desire of an individual to meet the expectations of others by following and adjusting the perceptions, beliefs or behaviour that other people or other groups do to be liked, and gain acceptance and avoid punishment or rejection from other people or other groups concerned. Meanwhile, informational influence is an aspect of conformity which refers to social influence based on the desire to be correct and have the right perception of life, thus affecting the tendency of individuals to accept and adapt to the perceptions, beliefs and behaviour of others based on trust or belief in the source of information received from another person or group, especially when faced with a difficult decision-making task.

\subsection{Self-Control}

Tangney et al. [32] revealed that the human ability to control himself is one of the strongest adaptive abilities and is beneficial for the welfare of the human soul. Self-control is an individual's capacity to be able to regulate or regulate himself which is manifested in the form of external behaviour [19]. According to Tangney et al. [32] self- control is a person's ability to change the response from within himself, suppress or withstand the desire to demonstrate a behaviour so as not to engage with unwanted behaviour. Self-control also helps individuals to change their responses or behaviour in line with social standards, be it ideals, values, morals, or social expectations aimed at achieving long-term goals [2].

\subsubsection{The Aspects of Self-Control}

Self-control is formed based on several aspects consisting of self-discipline, deliberate/non-impulsive, healthy habits, work ethics, and reliability [32]. Self-discipline refers to an individual's ability to discipline himself by focusing on doing various actions or tasks that must be done, and being able to refrain from getting involved with things that can interfere with concentration. Deliberate/non-impulsive refers to an individual's ability to withstand impulses from within himself so as not to take impulsive actions, to be able to carry out certain tasks or activities with various considerations, to be full of caution, calm, and not hurry, especially in making decisions. Healthy habits refers to an individual's ability to live healthy habits or patterns of life. Work ethics is related to the self-regulatory and ethical abilities possessed by individuals in carrying out a task or job, where the individual is able to give all his attention to the task he is doing, and is able to complete the task or job well and on time, and does not allow activities or other things to disturb him in completing the task he has to do. Finally, reliability refers to an individual's ability to carry out and implement a plan in a consistent manner in order to meet the achievement of certain goals [34].

\subsection{Cyberbullying}

Hinduja \& Patchin [8] defines cyberbullying as an act of harm and harm to other people which is carried out through the use of computers, cell phones, or other electronic devices by sending messages or content that are hurtful and degrading to victims or by uploading them in various online forums that are widely visited by other users. Meanwhile, according to Smith et al. [29] cyberbullying is aggressive behavior committed by certain individuals or groups on purpose and repeated from time to time using cell-phones or the internet to victims who are unable to defend themselves.

\subsubsection{Form of Cyberbullying}

Bauman [1] reveals that there are several forms of cyberbullying that can be done by a person, namely: (a) flaming, a form of cyberbullying that is done by sending angry, threatening, and hurtful words; (b) harassment, refers to cyberbullying activities carried out by sending threatening messages and taunts related to discrimination against a person's gender, race, age, sexual orientation, and so on; (c) denigration, refers to the activity of sending messages in the form of rumours or slander that are harsh 
and degrading to others, and uploading embarrassing content and images about other people, whether directed directly at the victim or by uploading them on various online sites; (d) masquerading, is a form of cyberbullying carried out by sending messages using the identity of another person, hacking e-mail accounts or accounts from other sites; (e) outing and trickery, done by sending or forwarding sensitive, personal and embarrassing information or content to others without the consent of the sender; (f) social exclusion, is a cyberbullying activity carried out by deliberately isolating and removing someone from an online chat room or deleting a friendship list on social networking sites; and (g) cyberstalking, refers to the activity of sending messages that are annoying, harassing, and hurting or threatening someone continuously so that the victim feels stressed and afraid.

\section{METHOD}

The type of research used is non-experimental correlation research with quantitative methods and the sampling technique used in this study was purposive sampling.

\subsection{Participants}

Participants in this research were adolescents of cyberbullying perpetrators, who were determined based on the result of a screening using the Cyberbullying Offending Scale measurement tool with an age range of 12-21 years who used and had accounts on the social networking site Instagram.

\subsection{Measures}

\subsubsection{Conformity}

Conformity was measured using conformity scale by Soetikno and Arimurti [30]. This scale measured through 16 items, include 9 positive items and 7 negative items. This scale also consists of two dimensions, namely (a) normative influence, to measure the tendency of participants to carry out the same activities as their group or to follow what the people around them do (e.g.: "I prefer to follow the people around me rather than argue with them"); and (b) informational influence, to measure the tendency of participants to accept suggestions or information from the group (e.g.: "I received the information I needed from the group"). Based on the results of the reliability test, the Cronbach's Alpha $(\alpha)$ value was 0.626 .

\subsubsection{Self-Control}

Self-control was measured using Self-control Scale by Tangney et al. [32]. This scale measured through 36 items, include 12 positive items and 24 negative items. This scale also consists of five dimensions, namely (a) self-discipline, to measure discipline in doing something (e.g.: "I am a lazy person"); (b) deliberate/non-impulsive, to measure the ability to withstand impulsive actions (e.g.: "I never let myself get out of control"); (c) healthy habits, to measure a healthy lifestyle (e.g.: "I do bad things for me if they are fun"); (d) work ethics, to measure self-regulation and ethics in carrying out daily work (e.g.: "I have a hard time saying no"); and (e) reliability, to measure the ability to handle a long-term task (e.g.: "I'm reliable"). Based on the results of the reliability test, the Cronbach's Alpha $(\alpha)$ value was 0.856 .

\subsubsection{Cyberbullying}

Cyberbullying was measured using Cyberbullying Offending Scale by Patchin and Hinduja [24]. This scale measured through 9 items by using a 5-point Likert scale format: point 1 for never choice answers; point 2 for onetime answer choices; point 3 for very few answer choices; point 4 for multiple answer choices; and point 5 for frequent answer choices. Example of items on this scale: "Write hurtful or malicious comments to others on Instagram". This scale is also used to assist researchers in screening participants whether participants are categorized as cyberbullying perpetrator or not. If the participant answers "never" to all items, then the participant is categorized as not a cyberbullying perpetrator. Based on the results of the reliability test, the Cronbach's Alpha $(\alpha)$ value was 0.781 .

\section{FINDINGS}

Based on data obtained about the sex of research participants from a total of 176 research participants, male participants total 49 people $(27.8 \%)$, female participants total 127 people $(72.2 \%)$.

The measurement of the conformity variable uses a measuring instrument that has a scale of 1 to 5 with a median or hypothetical mean of the measuring instrument is 3. Overall, the conformity variable data for the participants of this study has an empirical mean of 2.5611 . Based on these results, it can be said overall that the participants in this study tended to have a low level of conformity because they obtained a lower empirical mean score than the hypothetical mean score. Meanwhile, the measurement of the self-control variable uses a measuring instrument that has a scale of 1 to 5 with a median or hypothetical mean of the measuring instrument is 3 . As a whole, the data on self-control variables in this study participant has an empirical mean of 2.9219. Based on these results, overall, it can be said that the participants in this study tended to have a low level of self-control because they obtained a lower empirical mean score than the hypothetical mean score.

Based on the hypothesis of this study, an analysis of the role of conformity toward to self-control has result that $\mathrm{t}=$ $4.695, \mathrm{p}=0.000, \mathrm{R}$ square $=0.112$. These result means that conformity has a significant role to adolescence cyberbullying perpetrator self-control in the amount of $11.2 \%$. 


\section{DISCUSSIONS}

Based on the results of the hypothesis analysis in this study, it shows that conformity has a significant negative relationship with self-control in adolescent cyberbullying actors, where the lower the conformity of cyberbullying adolescents, the higher self-control in these adolescents. Vice versa, the higher the conformity of cyberbullying adolescents, the lower the self-control of these adolescents. Based on the results of the overall variable description analysis, the participants in this study are known to have low self-control. These results are similar to several previous studies conducted by Vazsonyi et al. [35] and Li et al. [14], where it is known that adolescents with low selfcontrol have a higher tendency to bully in cyberspace or cyberbullying. Researchers concluded that adolescents with low self-control find it difficult to regulate behaviour and hold back when faced with various temptations, so they are unable to produce appropriate behaviour and eventually engage in various deviant behaviours or aggression towards others, such as cyberbullying.

Participants in this study are also known to have low conformity. Based on these results, the researchers concluded that the participants' tendency to accept suggestions and participate in activities carried out by their peer groups tends to be low. These results indicate a discrepancy with previous research conducted by Liu and Tung [15] and Mawardah and Adiyanti [18], where in both studies it was found that adolescents who commit cyberbullying tend to have high conformity. Researchers suspect that this difference can be due to differences in the ages of the participants, where the research conducted by Liu and Tung [15] and Mawardah and Adiyanti [18] involved junior high school students with an age range of 12 to 14 years, while in this study involving adolescents who aged 12 to 21 years, but in practice, participants aged 18 to 21 years outnumbered participants aged 12 to 17 years. According to Morgan and Grubem [13], conformity to peers will increase along with individual development from childhood to adolescence, and will decline when individuals begin to enter adulthood. Thus, because most of the participants in this study were adolescents aged 18 to 21 years who had been in a transition period to adulthood, it allowed these adolescents to have a lower tendency to conform to their peer groups.

Meanwhile, this study itself has several limitations or shortcomings that can be corrected in future studies. First, the number of study samples or participants involved in this study was too small compared to the population of participants as a whole. Second, the participants that were obtained tended to be not evenly distributed, in which participants aged 12 to 17 were very few in number when compared to participants aged 18 to 21 years. In addition, there were also fewer male participants than female participants, so that the results of the study could not be generalized to adolescent cyberbullying as a whole. Third, data collection in this study uses a self-report measuring tool, so that it allows participants not to answer the questionnaire statement items according to the actual conditions experienced by the participants optimally.

\section{CONCLUSIONS}

Based on the results of the research and data analysis that has been carried out, the test results show that the research hypothesis is accepted. Therefore, referring to the results of this study, there are several suggestions that can be given to researchers who will conduct similar research in the future. First, further research is expected to involve a larger number of research samples and to equalize the number of male and female participants so that participants can be more representative of the study population. Second, further research is expected to use the interview method or use the mixed method research method in order to further explore and obtain information related to the variables studied in more depth.

Meanwhile, it is hoped that adolescents can improve their ability to control themselves by increasing self-discipline. In addition, adolescents are also expected to be able to overcome conformity demands from their group of friends by trying to voice their opinions or arguments more related to the activities their group carries out compared to just participating in these activities without careful consideration. Thus, adolescents can have more control over themselves and can control demands for conformity from their group which will help adolescents not engage in deviant behaviour, such as cyberbullying.

\section{REFERENCES}

[1] Bauman, S. (2015). Types of cyberbullying. Cyberbullying: What counselors need to know, 53-58. DOI: https://doi.org/10.1002/9781119221685.ch4

[2] Baumeister, R.F., Vohs, K.D., \& Tice, D.M. (2007). The strength model of self-control. Current Directions in Psychological Science, 16(6), 351-355. DOI: https:// doi.org/10.1111\%2Fj.1467-8721.2007.00534.x

[3] Bohang, F.K. (2017, Juli 21). Instagram jadi media "cyberbullying" nomor 1. Kompas. www.google.com/ amp/s/amp.kompas.com/tekno/read/2017/07/21/125006 7/instagram-jadi-media-cyber-bullying-nomor-1

[4] Chowdhry, A. (2017, Mei 31). Study says instagram is ranked the worst social app for causing young people to feel depressed. Forbes. www.forbes.com/sites/ amitchowdhry/2017/05/31/instagram-depression/ \#17a34f4c7453

[5] Clement, J. (2020, Agustus 21). Global social networks ranked by number of users 2020. Statista. www.statista.com/statistics/272014/global-socialnetworks-ranked-by-number-of-users/ 
[6] Ditch the Label. (2017, Juli). The annual bullying survey 2017. Ditch the Label. www.ditchthelabel. org/wp-content/uploads/2017/07/The-Annual-BullyingSurvey-2017-1.pdf

[7] Fauzan, F., Firman, F., \& Daharnis, D. (2018). Relationship between self-control and peer conformity with smoking behavior. International Conferences on Educational, Social Sciences and Technology, 233-239. DOI: https://doi.org/10.31227/osf.io/5xay9

[8] Hinduja, S., \& Patchin, J.W. (2008). Cyberbullying: An exploratory analysis of factors related to offending and victimization. Deviant behavior, 29(2), 129-156. DOI: https://doi.org/10.1080/01639620701457816

[9] Hinduja, S., \& Patchin, J.W. (2013). Social influences on cyberbullying behaviors among middle and high school students. Journal of Youth and Adolescence, 42(5), 711-722. DOI: https://doi.org/10. 1007/s10964-012-9902-4

[10] Hu, Y., Manikonda, L., \& Kambhampati, S. (2014). What we instagram: A first analysis of instagram photo content and user types. Icwsm.

[11] Kemp, S. (2020, Februari 18). Digital 2020: Indonesia. Datareportal. www.datareportal.com/reports/ digital-2020-indonesia

[12] Kowalski, R. M., Giumetti, G. W., Schroeder, A. N., \& Lattanner, M.R. (2014). Bullying in the digital age: A critical review and meta-analysis of cyberbullying research among youth. Psychol Bull, 140(4), 1073-1137. DOI: http://dx.doi.org/10.1037/a0035618

[13] Leono, M. (2019). Hubungan antara kontrol diri dan konformitas pada remaja perokok aktif [Skripsi sarjana tidak dipublikasikan]. Universitas Tarumanagara.

[14] Li, C. K., Holt, T.J., Bossler, A. M., \& May, D. C. (2016). Examining the mediating effects of social learning on the low self-control-Cyberbullying relationship in a youth sample. Deviant Behavior, 37(2), 126-138. DOI: https://doi.org/10.1080/01639625.2014. 1004023

[15] Liu, Z.J., \& Tung, Y.Y. (2018). The impact of peer relationships, conformity, and cognitive empathy of bystander behavioral intentions for cyberbullying. Chinese Journal of Psychology, 60(2), 101-124. DOI: 10.6129/CJP.201806_60(2).0002

[16] Lowry, P. B., Zhang, J., Wang, C., \& Siponen, M. (2016). Why do adults engage in cyberbullying on social media? An integration of online disinhibition and deindividuation effects with the social structure and social learning model. Information Systems Research, 27(4), 962-986. DOI: https://doi.org/10.1287/isre.2016. 0671

[17] Malihah, Z., \& Alfiasari, A. (2018). Perilaku Cyberbullying pada Remaja dan Kaitannya dengan Kontrol Diri dan Komunikasi Orang Tua. Jurnal Ilmu Keluarga \& Konsumen, 11(2), 145-156. DOI: https:// doi.org/10.24156/jikk.2018.11.2.145

[18] Mawardah, M., \& Adiyanti, M.G. (2014). Regulasi emosi dan kelompok teman sebaya pelaku cyberbullying. Jurnal Psikologi, 41(1), 60-73.

[19] Murray, K. T., \& Kochanska, G. (2002). Effortful control: Factor structure and relation to externalizing and internalizing behaviors. Journal of Abnormal Child Psychology, 30, 503-514. DOI: https://doi.org/10.1023/ A:1019821031523

[20] Myers, D. G. (2010). Social psychology (10th ed.). McGraw-Hill.

[21] Myers, D. G., \& Twenge, J. M. (2017). Social psychology (12th ed.). McGraw-Hill.

[22] Pabian, S., \& Vandebosch, H. (2014). Using the theory of planned behaviour to understand cyberbullying: The importance of beliefs for developing interventions. European Journal of Developmental Psychology, 11(4), 463-477. DOI: https://doi.org/10. $1080 / 17405629.2013 .858626$

[23] Papalia, D. E., Old, S. W., \& Feldman, R. D. (2009). Human development: Perkembangan manusia. Salemba Humanika.

[24] Patchin, J. W., \& Hinduja, S. (2015). Measuring cyberbullying: Implications for research. Aggression and Violent Behavior, 23, 69-74. DOI: https://doi.org/10. 1016/j.avb.2015.05.013

[25] Rice, F. P., \& Dolgin, K. G. (2008). The adolescence, development, relationship and culture. Pearson Education.

[26] Santrock, J. W. (2011). Life span development (13 ${ }^{\text {th }}$ Ed.). McGraw-Hill.

[27] Sasson, H., \& Mesch, G. (2017). The role of parental mediation and peer norms on the likelihood of cyberbullying. The Journal of Genetic Psychology, 178(1), 15-27. DOI: https://doi.org/10.1080/00221325. 2016.1195330

[28] Schneider, S. K., O’Donnell, L., Stueve, A., \& Coulter, R.W.S. (2012). Cyberbullying, school bullying, 
and psychological distress: A regional census of high school students. American Journal of Public Health, 102(1),171-177. DOI: https://dx.doi.org/10.2105\% 2FAJPH.2011.300308

[29] Smith, P.K., Mahdavi, J., Carvalho, M., Fisher, S., Russell, S., \& Tippett, N. (2008). Cyberbullying: Its nature and impact in secondary school pupils. Journal of Child Psychology and Psychiatry, 49(4), 376-385. DOI: https://doi.org/10.1111/j.1469-7610.2007.01846.x

[30] Soetikno, N., \& Arimurti, D. (2020). Role of selfconcept and conformity on bullies. Advance in Social Science, Education and Humanities Research, 422, 299301. DOI: https://dx.doi.org/10.2991/assehr.k.200323. 138

[31] Spiliotopoulos, T., \& Oakley, I. (2013, April). Understanding motivations for facebook use: Usage metrics, network structure, and privacy. In Proceedings of the SIGCHI Conference on Human Factors in Computing Systems, 3287-3296. DOI: https://doi.org/ $10.1145 / 2470654.2466449$

[32] Tangney, J. P., Baumeister, R. F., \& Boone, A. L. (2004). High self-control predicts good adjustment, less pathology, better grades, and interpersonal success. Journal of Personality, 72(2), 271-324. DOI: https:// doi.org/10.1111/j.0022-3506.2004.00263.X

[33] Taylor, S. E., Peplau, L. A., \& Sears, D. O. (2006). Social psychology (12 ${ }^{\text {th }}$ Ed.). Prentice-Hall.

[34] Ursia, N. R., Siaputra, I. B., \& Sutanto, N. (2013). Academic procrastination and self-control in thesis writing students of faculty of psychology, Universitas Surabaya. Jurnal Makara Seri Sosial Humaniora, 17(1), 1-18. DOI: $10.7454 / m s s h . v 17 i 1.1798$

[35] Vazsonyi, A.T., Machackova, H., Sevcikova, A., Smahel, D., \& Cerna, A. (2012). Cyberbullying in context: Direct and indirect effects by low self-control across 25 European countries. European Journal of Developmental Psychology, 9(2), 210-227. DOI: https://doi.org/10.1080/17405629.2011.644919 